\title{
Design and Build: Perception of Project Owners and Contractors on Cost in Java, Indonesia
}

\author{
Djojopranoto, A.W. ${ }^{*}$ and Benhart, B.L. ${ }^{1}$
}

\begin{abstract}
Design-build (DB) is a project delivery that has already been used widely in USA, UK, Singapore and in other countries. However, it is not widely used in Indonesia and there are limited studies available on DB. The purpose of this paper is to quantify project owners' and contractors' opinions about the perceived benefits of DB in terms of cost in Java, Indonesia. The quantitative research design using survey study was conducted to evaluate stakeholders' opinion on the impact of DB on cost. Survey forms with questionnaires were sent to ten project owners and ten contractors. Inferential statistics using t-test was used to compare the perception between them. The result shows that project owners and contractors agree that DB project delivery has some benefits on cost. However, implementation has to be improved in order for DB to be a preferable project delivery option.
\end{abstract}

Keywords: Constructability review; cost; design build; risk transfer; value engineering; variation order dispute and claims.

\section{Introduction}

Design-build (DB) is a project delivery that has been used widely in many different countries, such as USA, UK, and Singapore. In USA, DB usage is around one fifth of the market for new building works and $24 \%$ of the US $\$ 286$ billion of nonresidential construction output [1,2]. In UK, DB usage is about $23 \%$ of the market for new building works [2]. In Singapore, around 15\% projects were based on DB between 2002 and 2004 [3]. However, in Indonesia DB project delivery is not widely used and there are limited studies available on DB.

There are negative perceptions with regards to DB that may prevent stakeholders to apply it. Some stakeholders argue that DB projects may have lower quality, compromised aesthetics, and more maintenance issues compared to traditional Design Bid Build (DBB) projects. Others perceive that in DB there are less independent checks and balances compared to traditional forms. Moreover, DB contractors are assumed to be unable to give independent professional advice, unable to adopt the architects' recommendation, and curtail their power [4]. Stakeholders may be reluctant to apply DB project delivery if these views are not verified.

1 School of Construction Management Technology, Purdue University, Knoy Hall Room 453401 N. Grant St., West Lafayette, IN 47907, USA

* Corresponding author; e-mail: aw.pranoto@gmail.com

Note: Discussion is expected before June, 1 ${ }^{\text {st }} 2017$, and will be published in the "Civil Engineering Dimension", volume 19, number 2, September 2017.

Received 12 July 2016; revised 18 August 2016; accepted 16 December 2016.
This paper focuses only on cost, because cost is the most important factor for both contractors and owners in determining whether to use DB or DBB. For contractors, cost has become management's most critical decision in marketing activities and operational strategies [5]. For owners, lowest cost submitted by the tenderers is normally the main consideration in the selection process, since cost-based marketing approach is predominantly used in Indonesia [5]. Quality and time are not the main concern for this study because in DBB the owner has already set the required time limit and quality level in the bidding specification [6]. In DBB, quality and time variables are the results of the owner's decision rather than the contractor's capability to deliver the project.

Both DBB and DB project delivery have different characteristics in terms of marketing approach. DBB has more cost-based characteristics because contractors start by establishing the total cost of making product and they do not necessarily need to build relationship with prospective customers for future projects [6]. On the other hand, DB has more market-based characteristics, because contractors are required to find out customers' need and to give early cost certainty, before completing the design [6]. The different characteristics of DB and DBB will yield different perception from owners and contractors with regards to cost.

The purpose of this survey study is to quantify project owners' and contractors' opinions about the perceived benefits of DB on cost in Java. Identifying perceptions from different stakeholders who have experience in DB project delivery in Java will give information about the factors that are considered by them for selecting DB project delivery. The result of this study will also give indication whether the use of DB in Java has positive or negative impact on cost 
for both contractors and owners. The results may inform the project owners whether applying DB project delivery is suitable for them. The results may also inform local and foreign contractors in Java about the challenges with regards to DB project delivery. After identifying the factors and obtaining the results of this study, we can conclude with suggestions on how to improve DB project delivery for project owners and contractors to increase the use of DB in Java.

The hypothesis of this survey study is that DB project delivery is perceived better than traditional project delivery in terms of cost. The following statement represents the underlying logic for designing and conducting this study. If the owners' and contractors' perception through their experience shows that DB project can create cost saving more than DBB project, then the impact of DB projects on cost in Java is considered better

\section{Literature Review}

This literature review highlights the impact of Design Build (DB) project on cost. The first section describes definition, characteristics, responsibility, and requirement of DB project delivery. The second section elaborates cost as dependent variable. The third section summarizes previous studies that have been conducted to show the relationship between the impact of DB project delivery and cost.

\section{The Independent Variable: DB Project Delivery}

\section{Definition}

DB is a project delivery system where the owner contracts a single entity to perform both design and construction under a single DB contract [7]. DB is now a common project delivery as an alternative to the traditional design-bid-build (DBB).

\section{Characteristics}

The characteristics of DB project delivery is different from the traditional DBB. One of the main characteristics of DB project delivery is the early engagement of the contractor. In DB, the owner selects the contractor and architect teams at the start of the project before any design has been started. This allows the contractor to participate in the design process. Early engagement of the contractor allows "constructability review", "value engineering" and "integration" to happen [8].

\section{Constructability Review}

Constructability review is defined as "the optimum use of construction knowledge and experience in planning, design, procurement, and field operations to achieve overall project objectives" [7]. It encompasses a detail review of design drawings, specifications, and construction processes by an experienced construction engineer before a project is put out for bidding. The benefit of careful design administration is to ensure that all constructability inputs make its way into the final design as well as construction [8].

\section{Value Engineering}

Value Engineering (VE) is a systematic method to improve the "value" of goods or products and services by using an examination of function. VE during the design process allows entities to gather and jointly search for opportunities to add value while reducing cost [7]. The main purpose of value engineering is to enhance the project, to be less susceptible to cost and time growth resulting from design errors and omissions. Therefore, the design team is expected to "design to budget" [8]. Through VE, owners may ask the contractor to "show the best facilities with the greatest value that meets their needs and budget", instead of "what the building cost will be".

\section{Integration}

Integration is defined as merging of different disciplines with different goals, needs, and cultures into a cohesive and mutually supporting unit [9]. The integrated approach provides numerous advantages for both technical and social aspects such as improvements to the construction solution, better communication, achieve the best value, and transfer of expertise between all the parties [10]. DB places the designer and constructor on equal professional footing so that they can provide unified recommendations and jointly develop solution to the owner [8]. Design and construction personnels, who are working and communicating as a unit, can evaluate alternatives, choosing systems, methods, and materials that enhance the project.

\section{Responsibility}

The design responsibility is transferred from the owner's organization to the DB contractor who is responsible for the design management as well as the construction process. DB contractor becomes the leading role in the design management of $\mathrm{DB}$ projects, not because the $\mathrm{DB}$ contractor is better qualified but it reflects the reality of risk allocation in the minds of project participants [11]. DB contractor needs to achieve the "program requirements" and "performance requirements". The program requirements or programs, describe the functional and quantitative needs of the project, such as a proposed building's net floor area and the number of vehicles 
to be accommodated [8]. The performance requirements are described in the specifications and include the owner's expectations for the performance of the facility and its component parts, building assemblies, and materials.

\section{Requirement}

There are few requirements expected from each stakeholder that contribute to the success of DB project. Owners should be familiar with the construction process if they want to use DB contractual arrangement [12]. For owners who do not have in-house staff with expertise in preparing and administering design-build Request for Proposals (RFP) and contracts, a DB consultant or design criteria professional should be retained to prepare scope definition and RFP documents [8]. Contractors should have good track record for completing projects on budget, on schedule and to acceptable level of quality. Contractor should also have good design capability, high technical expertise and adequate plant and equipment [13].

\section{The Dependent Variable: Cost}

\section{Cost}

Cost is the amount of money paid by an owner for a facility. Cost is limited to the design and construction of the facility and does not include land acquisition, extensive site work, process equipment or owner costs [14]. Cost measures include unit cost and cost growth. Unit cost was measured to indicate the relative cost of a facility for its given area. It is represented by the following expression:

Unit Cost $\left(\right.$ dollar $\left./ m^{2}\right)=($ Final Project Cost $/$ Area $) /$ Index (1)

Cost Growth (CG) was measured to indicate growth of project costs over the life of the job. It is defined by the following expression: $\begin{array}{rl}C G(\%)= & {[\text { Final Project Cost }- \text { Contract Project Cost }) /} \\ & \text { Contract Project Cost }] * \\ * & 100 \%\end{array}$

\section{Impact of DB Project Delivery on Cost}

A survey by Molenaar et al. [15] revealed that reduction in cost is the second most important reason for clients to select DB. In USA, study on DB project performance was conducted using case-study questionnaires sent to 512 public-sector owners. It revealed that cost performance was excellent with $59 \%$ of the DB projects within $2 \%$ of the budget established [15]. Another comparison study conducted by Konchar and Sanvido also showed that the effect of DB project delivery methods indicated that the unit cost in DB projects were at least $6.1 \%$ less costly than comparable DBB projects and the cost grew at least 5.2\% less than DBB [14]. In UK, survey questionnaires were sent to 100 architects [16]. The architects confirmed that $75 \%$ of DB projects were completed within $5 \%$ of the budget, compared to $63 \%$ of traditional projects.

There is another view with regards to the impact of DB on project cost. In USA, Ernzen and Schexnayder published a paper about analysis of the company's labor cost risk based on a case study of DB and DBB projects [17]. They found that DB projects are riskier, and the average profit margin was only $3.5 \%$ bigger than that for non-DB work. In UK, Pain and Bennett conducted interviews with the project owners from 49 projects [18]. They concluded from their case studies that the cost of DB projects might be the same as traditional DBB projects. Turner also conducted surveys of contractors, designers, and building clients regarding design build issues in the UK [19]. He suggested that there was no evidence to indicate any differences in the prices tendered under either DB or traditional methods.

There are other downfalls of DB project delivery that were found by some studies. Ling found that the disadvantage of having contractor appointed architects was that cost growth may be higher [13]. Higher bidding cost for DB contracts was also mentioned by some studies. Latham found that the bidding price was more than twice of that of traditional procurement routes [20]. Rowlinson commented that a lot of resources were committed to prepare a DB tender and the risks of not being awarded the contract are usually high [21]. With regard to professional fees, architects felt that contractors tended to reduce professional fees in DB projects [22].

\section{Research Methods}

A quantitative study using a survey form was conducted in order to quantify owners' and contractors' opinions on the perceived benefits of DB on cost in Java. The samples were 10 project owners and 10 contractors who had experience with DB project in Java. The inclusion criteria for project owners was project owners that had applied or used DB project delivery and agreed to participate in the study. Inclusion criteria for contractors was general/prime contractors that had applied or used DB project delivery in the past and agreed to participate in the study. The exclusion criteria for project owners were project owner that had less than 5 years of experience. The exclusion criteria for contractors were contractor that had less than 5 years of experience. Convenience sampling was used since there were limited DB users in Java. 
Table 1. Statistical Results of Clients and Contractor's Ratings

\begin{tabular}{|c|c|c|c|c|c|c|c|}
\hline \multirow{2}{*}{ No. } & \multirow{2}{*}{ DB Performance Statements } & \multicolumn{3}{|c|}{ Clients } & \multicolumn{3}{|c|}{ Contractors } \\
\hline & & Mean & t-value & Sig & Mean & t-value & Sig \\
\hline $\mathrm{H} 1$ & $\begin{array}{l}\text { The risk of costs exceeding budget is minimal in } \mathrm{DB} \\
\text { projects }\end{array}$ & 3.600 & 2.250 & 0.026 & 3.900 & 3.857 & 0.002 \\
\hline $\mathrm{H} 2$ & $\begin{array}{l}\text { DB contractors able to use value engineering to } \\
\text { reduce costs without reducing quality }\end{array}$ & 4.200 & 6.000 & 0.000 & 4.300 & 8.510 & 0.000 \\
\hline H3 & $\begin{array}{l}\text { DB contractors use value engineering to increase } \\
\text { quality without increasing costs }\end{array}$ & 4.000 & 4.743 & 0.001 & 4.000 & 3.873 & 0.002 \\
\hline $\mathrm{H} 4$ & $\begin{array}{l}\text { Contractors propose reasonable professional fees in } \\
\text { DB projects }\end{array}$ & 4.000 & 6.708 & 0.000 & 3.700 & 3.280 & 0.005 \\
\hline $\mathrm{H} 5$ & $\begin{array}{l}\text { DB contractors pursue cheaper design solutions all } \\
\text { the time }\end{array}$ & 3.200 & 0.688 & 0.254 & 3.600 & 2.250 & 0.026 \\
\hline $\mathrm{H} 6$ & $\begin{array}{l}\text { DB contractors make use of standardized } \\
\text { components to reduce cost }\end{array}$ & 3.800 & 4.000 & 0.002 & 3.800 & 4.000 & 0.002 \\
\hline $\mathrm{H} 7$ & $\begin{array}{l}\text { DB contractors make use of efficient construction } \\
\text { method to reduce cost }\end{array}$ & 3.900 & 3.250 & 0.005 & 4.500 & 9.000 & 0.000 \\
\hline H8 & $\begin{array}{l}\text { The usage of DB procurement route provides clients } \\
\text { with early knowledge of the maximum project cost }\end{array}$ & 4.200 & 4.129 & 0.001 & 3.900 & 3.250 & 0.005 \\
\hline H9 & $\begin{array}{l}\text { DB contractual arrangement leads to fewer } \\
\text { disputes and claims }\end{array}$ & 3.800 & 2.228 & 0.026 & 3.900 & 3.250 & 0.005 \\
\hline H10 & $\begin{array}{l}\text { Transferring design performance to DB contractor } \\
\text { will help to lower overhead cost }\end{array}$ & 4.300 & 4.333 & 0.001 & 4.200 & 6.000 & 0.000 \\
\hline H11 & $\begin{array}{l}\text { Transferring design performance to DB contractor } \\
\text { will help to lower project risk }\end{array}$ & 4.800 & 13.500 & 0.000 & 4.000 & 4.743 & 0.001 \\
\hline H12 & $\begin{array}{l}\text { Performance specification used in DB projects helps } \\
\text { to reduce project cost }\end{array}$ & 4.000 & 3.354 & 0.004 & 4.300 & 8.510 & 0.000 \\
\hline H13 & $\begin{array}{l}\text { Constructability review from the contractor help to } \\
\text { lower the project cost }\end{array}$ & 4.100 & 4.714 & 0.001 & 4.000 & 6.708 & 0.000 \\
\hline H14 & $\begin{array}{l}\text { Overlapping of design and construction period in } \\
\text { DB project help to reduce the project cost }\end{array}$ & 3.300 & 0.709 & 0.248 & 3.300 & 0.669 & 0.260 \\
\hline $\mathrm{H} 15$ & There are less variation orders (VO) in DB projects & 3.600 & 1.964 & 0.041 & 4.200 & 9.000 & 0.000 \\
\hline
\end{tabular}

The questionnaire used in this study was developed from the literature review as well as adapted from questionnaire developed by Ling and Leong [22]. The questionnaire was sent to project owners and contractors in Java who were selected and qualified to participate in the survey. After the questionnaires were prepared, copies were sent out. Each questionnaire was accompanied by a cover letter indicating the objectives of the research and attached with a self-addressed and stamped envelope. The responses were returned within a month of mailing.

Instrument used was questionnaire containing three parts: demographic overview, DB related questions, and suggestion for improvement. The demographic overview asked the participants about the numbers of DB projects they have handled and the years of experience in the construction industry. The DB related questions contained 15 questions that describe the impact of DB project delivery with cost. Respondents were asked to state their level of agreement or disagreement with the issues raised on a five-point Likert scale, where 1 is strongly disagree, 2 is disagree, 3 is neutral, 4 is agree, and 5 is strongly agree. The cut point of perception considered beneficial is 3 and above. The last part of the questionnaire asked the participants to give brief suggestion on how to improve DB project delivery.
The t-test is used in this survey study to compare the difference between the mean scores of two samples. It can deal with situations in which the sample size is not large and a standard normal distribution may not exist [23]. Mean ratings for all statements related to DB performance were calculated for each category of the respondents using the Excel PH Stat4. These mean ratings are merely those of the sample. It is therefore necessary to find out whether the population would agree with these DB performance attributes by performing t-test .

For each performance attribute, the null hypothesis that the attribute did not receive agreement amongst the population and the alternative hypothesis that the attribute was agreed, are set out below. The null hypothesis Ho: $\mu \leq \mu$ o against the alternative hypothesis $\mathrm{H} 1: \mu>\mu$ o, where $\mu$ is the population mean. $\mu \mathrm{o}$ is the critical rating above which the attribute is considered agreeable by the population. In this study, $\mu$ o was fixed at 3 , because by the definition given in the rating scale, ratings above 3 (i.e. 4 and 5) represented 'agree' and 'strongly agree'. The significance level was set at 0.05 . When $p<0.05$, it can be concluded that the population agree with the statement at a $95 \%$ confidence level. 


\section{Results and Discussion}

There were 20 responses gathered for this survey; ten responses received from project owners and ten responses received from contractors. The length of the project owners' experiences varied from six to 30 years while the length of the contractors' professional experiences varied from ten to 32 years. All of the project owners and contractors are familiar with DB project delivery from their experiences. Most of the project owners and contractors have applied DB project delivery system in their works, ranging from one to five projects. Thirty percent of the project owners have experienced with more than ten DB projects. DB project delivery system was applied mostly in commercial building projects, by both project owners and contractors. Only few project owners have applied DB project delivery system in industrial building projects. Similarly, there were only few contractors that have applied DB project delivery system in constructing parking buildings.

Table 1 shows that both project owners and contractors agree that there are potential benefits that DB project delivery can bring to lower the project cost and professional fee. DB contractors are able to use value engineering to reduce costs without reducing quality (H2) and to increase quality without increasing costs (H3). This is in concordance with Ling and Leong that DB contractors should have conducted value engineering to make their offers more competitive and proposed design solutions that reduce cost without reducing quality, or increase quality without increasing cost [22]. Both the project owners and contractors agree that $\mathrm{DB}$ project delivery allows DB contractors to make use of efficient construction methods to reduce cost $(\mathrm{H} 7)$ and to perform constructability review to lower the project cost (H13). An example of this efficiency can be found in the use of standardized components to reduce cost (H6). Both the project owners and contractors agree that with regards to the project cost, the usage of DB procurement route provides clients with early knowledge of the maximum project cost (H8). This is in concordance with Tam that the client can obtain a firm price for the project at the outset [24]. Both the project owners and contractors also agree that with regards to the design and coordination fee, contractors propose reasonable professional fees in DB projects $(\mathrm{H} 4)$.

Table 1 also shows that both project owners and contractors agree that there are potential benefits that DB project delivery can bring to reduce the risk, dispute, claims and variation o rder (VO). Both the project owners and contractors agree that the risk of costs exceeding budget is minimal in DB projects (H1). This is in accordance to Bennett et al.'s study that DB projects are more likely to be completed on budget, or budget variance within 5\%. Overall, $75 \%$ of DB projects were completed with budget variance within $5 \%$, compared to $63 \%$ of traditional projects [2]. This is due to the perception that transferring design job to DB contractors enables project owners to lower project risk (H11) and to lower overhead cost (H10). This confirms the findings of Ernzen and Schexnayder, that DB projects are riskier for contractors, and the average profit margin for them was only $3.5 \%$ greater than that for non-DB work [17].

Both project owners and contractors agree that DB contractual arrangement leads to fewer disputes and claims (H9) and there are less variation orders (VO) in DB projects (H15). This confirms the findings by Songer and Molenaar that the cost performance was excellent with $59 \%$ of the DB projects were within $2 \%$ of the budget variance, when the DB contractor was hired [25]. Both parties also agreed that performance specifications and performance requirements should be set by project owners in DB projects and this helps to reduces project cost (H12). This confirms the finding by Oztas and Okman that clients should specify their requirements comprehensively in the bid documents, expect to get only what is specified in the DB contract documents and should refrain from ordering excessive changes [26].

Although project owners and contractors agree that there are benefits that DB project delivery can lower the cost and claims, they also disagree in a few areas. Project owners disagree that DB contractors pursue cheaper design solutions all the time (H5). This contradicts the finding by Ling and Leong that clients and architects felt that the cost of DB projects may be lower because contractors pursue cheaper design solution all the time [22]. Project owners and contractors disagree that overlapping of design and construction period in DB project help to reduce the project cost (H14). This contradicts the finding by Ling and Leong that detailed working drawings are not necessary as design can be developed as construction is ongoing [22].

\section{Conclusion}

The finding shows that both project owners and contractors agree that DB project delivery system has potential benefits on cost. Project owners selected DB project delivery because it offers value engineering and constructability review that can lower the construction cost. The project owners have better control in keeping their budget because they can get early knowledge of the maximum project cost early. The project owners transfer most of the project 
risk to the contractors. With this conditions there tend to be less variation orders and less risk of costs exceeding budgets in DB projects. However, there are requirements that project owners have to accomplish in order to implement DB successfully. The finding suggests that performance specification must be set clearly and overlapping design and construction can increase the project cost. In this case, it is recommended that project owners should set clear design criteria, set a targeted budget and verify the performance specification in DB projects. Project owners should also firm up their design early and not significantly change it during construction to minimize variation order. If project owners can utilize DB project delivery system successfully and they can generate more cost saving through DB, they will have preference towards DB over the time.

The finding shows that contractors agree that DB contractual arrangements have some benefits for them since it leads to fewer dispute and claims and there are less variation orders in DB project delivery. In securing projects through DB project delivery, contractors have more involvement with the project owners and have more responsibility in keeping the project cost not to exceed the budget. In that case, DB contractors have to have experience in doing constructability review, value engineering, and design management. Their expertise with regards to construction method, materials, and parametric costing should be honed to give useful insights to project owners. DB contractors should also be able to give a credible input about maximum project cost and schedule. Since the finding confirms that DB projects are riskier for contractors. DB contractors should have relevant experiences and competencies to manage DB projects and have the right personnel. Satisfactory result with regards to cost saving in DB project delivery should also be promoted by the DB contractors to other clients to increase the use of DB project delivery in Java.

\section{Acknowledgement}

The authors wish to acknowledge the support of Dr. Randy Rapp from Purdue University for his guidance and support. Thanks also expressed to Mr. Liong Tju Chung from Tarumanagara University for his statistical advice.

\section{References}

1. Tarricone, P., Design-Build It, and They Will Come, Facilities Design \& Management, 15(9), 1996, pp. 60-63.

2. Bennett, J., Pothecary, E., and Robinson, G., Designing and Building a World-class Industry: The University of Reading Design and Build Forum Report, Centre for Strategic Studies in Construction, 1996.
3. Ling, F.Y. and Kerh, S., Comparing the Performance of Design-Build and Design-Bid-Build Building Projects in Singapore, Architecture Science Review, 47, 2006, pp. 163-175.

4. Ling, F., Ofori, G., and Low, P.L., Importance of Design Consultants' Soft Skills in Design-Build Projects, Engineering, Construction, and Architectural Management, 7, 2000, pp. 389-398.

5. Mochtar, K. and Arditi, D., Alternate Pricing Strategies in Construction, Dimensi Teknik Sipil, 2(1), March 2000, pp. 56-64.

6. Farimani, R. and Wright, E., Marketing Strategies for Design Build Delivery System, ASC Proceedings of the 40th Annual Conference 2004, Utah, Bringham Young University.

7. Koch, J.E., Gransberg, D.D., and Molenaar, K.R., Project Administration for Design-Build Contracts, American Society of Civil Engineers. Virginia, 2010.

8. Beard, J.L., Loulakis, M.C., and Wundram, E.C., Design Build Planning through Development, McGraw-Hill, New York, 2001.

9. Takim, R., Esa, M.R., and Hamidah, S.H., Delivering Best Value for Design and Build (D\&B) Projects through Integrated Process Improvement Solution, Procedia Social and Behavioral, 101, 2013, pp. 62-70.

10. Vrijhoef, R. and Voordijk, H., Improving Supply Chain Management in Construction, CIB Joint International Symposium of Knowledge Construction, 2003, Singapore.

11. Chen, E.H. and Yu, A.T., Contract Design Management in the Design and Build System, International Journal of Project Management, 2005, pp. 630-639.

12. Ndekugi, I. and Turner, A., Building Procurement by Design and Build Approach, Journal of Construction Engineering and Management, 2, 1994, pp. 243-256.

13. Ling, F.Y., How Project Managers can Better Control the Performance of Design-Build Projects, International Journal of Project Management, 22, 2004, pp. 477-488.

14. Konchar, M. and Sanvido, V., Comparison of US Project Delivery Systems, Journal of Construction Engineering and Management, 124, 1998, pp. 435-444.

15. Molenaar, K.R., Songer, A.D., and Barash, M., Public Sector Design/Build Evolution and Performance, Journal of Management in Engineering, 15, 1999, pp. 54-62.

16. Akintoye, A. and Fitzgerald, E., Design and Build: A Survey of Architects' Views, Engineering, Construction and Architectural Management, 2(1), 1995, pp. 27-44.

17. Ernzen, J. and Schexnayder, C., One Company's Experience with Design/Build: Labor Cost Risk and Profit Potential, Journal of Construction Engineering and Management, 126, pp. 10-14. 
18. Pain, J. and Bennett, J., JCT with Contractor's Design Form of Contract: The Study in Ise, Construction Management and Economics, 6, 1988, pp. 307-337.

19. Turner, D.F., Design and Build Contract Practice. Longman Scientific and Technical, Harlow, 1995.

20. Latham, M., Constructing the Team, HMSO, London, 1994.

21. Rawlinson, S., Design Build - Its Development and Present Status, CIOB. Ascot, 1987.

22. Ling, F. and Leong, E., Performance of DesignBuild Projects in Terms of Cost, Quality, and Time: Views of Client, Architects and Contractors in Singapore, The Australian Journal of Construction Economics and Building, 2, 2002, pp. 37-46.
23. Newbold, P., Statistics for Business and Economics, $3^{\text {rd }}$ ed., Prentice Hall, Englewood Cliffs, 1991.

24. Tam, C.M., Design and Build on a Complicated Redevelopment Project in Hong Kong: The Happy Valley Race Course Redevelopment, International Journal of Project Management, 18, 2000, pp. 125-129.

25. Songer, A.D. and Molenaar, K.R., Selecting Design-Build: Public and Private Sector Owner Attitudes, Journal of Management in Engineering, 12, 1996, pp. 47-53.

26. Oztas, A. and Okmen, O., Risk Analysis in Fixed-Price Design-Build Construction Projects. Building and Environment, Building and Environment, 39, 2004, pp. 229-237. 